\title{
Erratum to: The Relationship Among Sexual Attitudes, Sexual Fantasy, and Religiosity
}

Tierney K. Ahrold • Melissa Farmer •

Paul D. Trapnell $\cdot$ Cindy M. Meston

Published online: 29 May 2011

(c) Springer Science+Business Media, LLC 2011

Erratum to: Arch Sex Behav (2011) 40:619-630 DOI 10.1007/s10508-010-9621-4

The acknowledgements for this article should read: This research was supported, in part, by Grant Number R01 HD51676 from the
National Institute for Child Health and Human Development to Cindy M. Meston. Its contents are solely the responsibility of the authors and do not necessarily represent the official views of the National Institute for Child Health and Human Development.

The online version of the original article can be found under doi:10.1007/s10508-010-9621-4.

T. K. Ahrold · C. M. Meston ( $₫)$

Department of Psychology, University of Texas at Austin,

108 E. Dean Keeton, Austin, TX 78712, USA

e-mail: meston@psy.utexas.edu

M. Farmer

Department of Psychology, McGill University,

Montreal, QC, Canada

P. D. Trapnell

Department of Psychology, University of Winnipeg,

Winnipeg, MB, Canada 